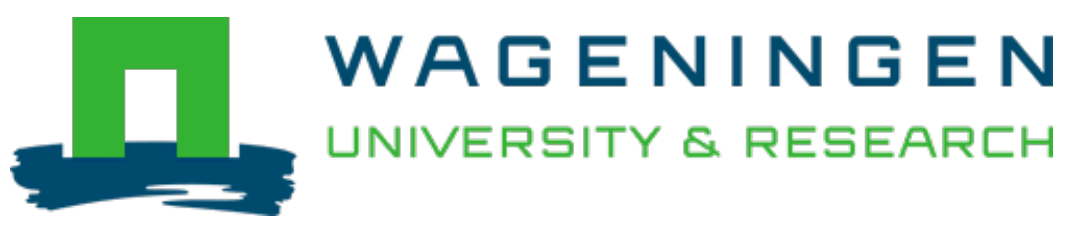

\title{
A survey on the microbiological and chemical composition of buffalo milk in China
}

\section{Food Control}

Han, B.Z.; Meng, Y.; Li, M.; Yang, Y.; Ren, F. et al

https://doi.org/10.1016/j.foodcont.2006.03.011

This publication is made publicly available in the institutional repository of Wageningen University and Research, under the terms of article $25 \mathrm{fa}$ of the Dutch Copyright Act, also known as the Amendment Taverne. This has been done with explicit consent by the author.

Article 25 fa states that the author of a short scientific work funded either wholly or partially by Dutch public funds is entitled to make that work publicly available for no consideration following a reasonable period of time after the work was first published, provided that clear reference is made to the source of the first publication of the work.

This publication is distributed under The Association of Universities in the Netherlands (VSNU) 'Article $25 \mathrm{fa}$ implementation' project. In this project research outputs of researchers employed by Dutch Universities that comply with the legal requirements of Article $25 \mathrm{fa}$ of the Dutch Copyright Act are distributed online and free of cost or other barriers in institutional repositories. Research outputs are distributed six months after their first online publication in the original published version and with proper attribution to the source of the original publication.

You are permitted to download and use the publication for personal purposes. All rights remain with the author(s) and / or copyright owner(s) of this work. Any use of the publication or parts of it other than authorised under article $25 \mathrm{fa}$ of the Dutch Copyright act is prohibited. Wageningen University \& Research and the author(s) of this publication shall not be held responsible or liable for any damages resulting from your (re)use of this publication.

For questions regarding the public availability of this publication please contact openscience.library@wur.nl 


\title{
A survey on the microbiological and chemical composition of buffalo milk in China
}

\author{
Bei-Zhong Han ${ }^{\text {a,b }}$, Yun Meng a , Min Li a , Ying-Xiao Yang ${ }^{\text {a,b }}$, Fa-Zheng Ren ${ }^{\text {a,b,*, }}$ \\ Qing-Kun Zeng ${ }^{\text {b,c }}$, M.J. Robert Nout ${ }^{\mathrm{d}}$ \\ ${ }^{\text {a }}$ College of Food Science and Nutritional Engineering, China Agricultural University, Beijing 100083, China \\ ${ }^{\mathrm{b}}$ Key Laboratory of Functional Dairy, Ministry of Education, Beijing 100083, China \\ ${ }^{c}$ Guangxi Buffalo Research Institute, Chinese Academy of Agricultural Science, Nanning 530001, China \\ ${ }^{\mathrm{d}}$ Laboratory of Food Microbiology, Wageningen University, Wageningen EV 6700, The Netherlands
}

Received 13 November 2005; received in revised form 13 March 2006; accepted 13 March 2006

\begin{abstract}
One hundred and twelve samples of raw buffalo milk were collected at four locations in China, and their microbiological and chemical composition was analyzed. Average levels of major components were: fat $7.59 \%$ (v/v), crude protein $4.86 \%$ (w/w), lactose $4.74 \%$ (w/w), total solids $18.44 \%(\mathrm{w} / \mathrm{w})$, ash $0.85 \%(\mathrm{w} / \mathrm{w})$, and $\mathrm{pH}$ 6.65. The crude protein, fat, total solids and ash contents of milk from multi-crossbreed buffalo were higher than those of river buffalo's, but lower than those of crossbreed $\mathrm{F}_{1}$ and $\mathrm{F}_{2}$ buffalo's. Microbiological enumeration revealed counts of total mesophilic aerobic bacteria of $5.59 \log \mathrm{cfu} / \mathrm{ml}$, bacterial endospores 2.31 , lactic acid bacteria 4.62 , fungi 1.79, coliforms 2.42, Escherichia coli 1.53, and Staphylococcus aureus 1.68. Listeria spp. were below detection level in all of the samples. The microbiological quality of buffalo milk was judged marginal and indicates the need for improved hygienic standards.
\end{abstract}

(C) 2006 Elsevier Ltd. All rights reserved.

Keywords: Buffalo milk; Chemical composition; Microbiological quality; Safety

\section{Introduction}

Buffalo milk receives increasing research interest and investment in various countries, owing mainly to its attractive nutrient content (Amarjit \& Toshihiko, 2003). Compared with cow milk, buffalo milk has a higher content of fat, crude protein, lactose, total solids, vitamins and minerals, which impart a rich flavour and taste, and make it a highly suitable ingredient for the manufacture of a wide variety of milk products, such as cheese, butter fat, ice cream, and yoghurt (Fundora et al., 2001). As in any raw milk, microorganisms can multiply rapidly in buffalo milk due to its high nutrient content. Previous studies on the microbiological quality of buffalo milk have revealed the

\footnotetext{
* Corresponding author. Address: College of Food Science and Nutritional Engineering, China Agricultural University, Beijing 100083, China. Tel./fax: +86 1062736638 .

E-mail address: renfz@cau.edu.cn (F.-Z. Ren).
}

presence of, e.g., coliform bacteria, Escherichia coli, lactic acid bacteria, Listeria monocytogenes, yeasts, moulds, Staphylococcus spp. and Clostridium spp. (Boycheva, Dimitrov, Tsankova, \& Iliev, 2002). The occurrence of high levels of spoilage bacteria and pathogens might lead to the deterioration of buffalo milk, and present a potential health hazard.

China is among the largest producer countries of buffalo milk, with both buffalo herds and buffalo milk production listed third worldwide in 2004, after those of India and Pakistan (FAO, 2004). Two types of buffalo, namely River type and Swamp type, are distinguished. The former have been developed mainly in the Indian subcontinent and are used for milk production, whereas the latter, which has historically predominated in south China, are considered excellent animals for work but poor milk producers. Therefore, Guangxi province has strived for several years to enhance milk production by crossbreeding the native swamp buffalo with river buffalo breeds such as Murrah 
and Nili-Ravi, and obtained fertile crossbreed offspring, leading to a great improvement of the yield of buffalo milk (Amarjit \& Toshihiko, 2003). Due to their particular inclination for hot and humid tropical climates, buffalo are primarily reared in southern China, such as Guangxi and Yunnan provinces (Han \& Ding, 1994). These two provinces have large buffalo populations, ranking first and third respectively nationwide, and were thus selected as representatives to conduct the present survey.

Considering its economic potential, extensive and intensive exploitation of buffalo milk can contribute to satisfy the nutrient requirements of the Chinese public and to increase the income of buffalo farmers. Given the growing public awareness of the importance of food safety and quality, knowledge of the microbial and chemical composition of buffalo milk is of great significance for further development of its hygienic processing into high quality consumer products. As yet, information on such aspects is scant and scattered.

The objective of this study is, therefore, to investigate the occurrence and load of microorganisms in buffalo milk, with special reference to food-borne pathogens. The results obtained serve as baseline data and will be useful in future studies dealing with pathways of contamination and in the development of HACCP systems for hygienic processing of buffalo milk. The study also presents information on physicochemical parameters such as total solids, crude protein, lactose and fat content, to enable an appreciation of the nutritional value of buffalo milk.

\section{Materials and methods}

\subsection{Sampling}

Samples of buffalo milk were obtained from Xingning and Yongning of Nanning in Guangxi autonomous region, and Xiaguan and Weishan of Dali in Yunnan province of China. Milking was done manually twice a day, at 7:00 am and 5:00 pm.

Sampling was carried out both at large buffalo farms and scattered households. A total of 112 samples of buffalo milk were collected from five types of buffalo representing the typical breeds in Guangxi and Yunnan. These included crossbreed (river buffalo $\hat{\gamma} \times$ swamp buffalo 9$)\left(F_{1}\right.$ and $F_{2}$, 32 samples each) and 16 samples each from pure river buffalo and multiple crossbreed $\left(\mathrm{F}_{\mathrm{H}}\right)$. At each location, samples of approximately $500 \mathrm{ml}$ milk were taken aseptically from the bulk milk container into sterile glass bottles. The milk was collected within 15 min of milking at ambient temperatures, kept on ice during $\approx 2 \mathrm{~h}$ transport and was analyzed immediately after arrival at the laboratory.

\subsection{Chemical analysis}

\subsubsection{Fat content and crude protein}

Fat content and crude protein were determined by the Babcock, and Kjeldahl methods, respectively.

\subsubsection{Lactose}

Lactose was determined by colorimetric method according to the Chinese standard method (GB/T 16285-1996).

\subsubsection{Total solids and $p H$}

Total solids were determined by conventional ovendrying $\left(60^{\circ} \mathrm{C}\right.$ for $2-3 \mathrm{~h}$, then $100^{\circ} \mathrm{C}$ for $\left.6 \mathrm{~h}\right)$ of $5 \mathrm{~g}$ milk sample. The $\mathrm{pH}$ was measured using a digital $\mathrm{pH}$ meter (pH 211 microprocessor pH meter, Hanna Instruments, Italy); calibration was done with buffers of $\mathrm{pH} 4.00$ and pH 6.80 .

\subsubsection{Ash}

A $10 \mathrm{~g}$ sample was evaporated in a water bath and then heated in a muffle furnace at $550{ }^{\circ} \mathrm{C}$ for $3 \mathrm{~h}$, until the ash residue remained.

\subsection{Microbiological analysis}

\subsubsection{Sample treatment}

Representative $20 \mathrm{~g}$ portions were aseptically weighed, mixed with $180 \mathrm{ml}$ peptone saline $(0.1 \%$ neutral peptone, $0.9 \% \mathrm{NaCl}$ ), and homogenized by shaking. Subsequent decimal dilutions were prepared with the same diluent, and in all cases, duplicate counting plates were prepared of appropriate dilutions.

\subsubsection{Total count of mesophilic aerobic bacteria (TC)}

TC was enumerated according to Chinese standard method GB/T4782.2-2003, in pour-plates of plate count agar (PCA, CM325, Oxoid England), after incubation at $37^{\circ} \mathrm{C}$ for $2 \mathrm{~d}$.

\subsubsection{Bacterial endospores (BS)}

Buffalo milk samples were pasteurized $\left(80^{\circ} \mathrm{C}, 10 \mathrm{~min}\right)$ and BS were enumerated in pour-plates of PCA, after incubation at $37^{\circ} \mathrm{C}$ for $2 \mathrm{~d}$.

\subsubsection{Lactic acid bacteria ( $L A B)$}

LAB were enumerated according to Chinese standard method GB/T4789.35-2003, in pour-plates of de Man, Rogosa and Sharpe medium (MRS, Merck, Germany), after incubation at $37^{\circ} \mathrm{C}$ for $3 \mathrm{~d}$.

\subsubsection{Yeasts and moulds (fungi)}

Fungi were enumerated in pour-plates of rose Bengal medium (RBM, Luqiao, China), after incubation at $30{ }^{\circ} \mathrm{C}$ for $3-5 \mathrm{~d}$.

\subsubsection{Coliform bacteria and E. coli}

Coliforms were enumerated using $3 \mathrm{M}$ Petrifilm ${ }^{\mathrm{TM}}$ E. coli/ Coliform plates (3M, USA), after incubation at $37^{\circ} \mathrm{C}$ for $1 \mathrm{~d}$, and E. coli for $2 \mathrm{~d}$.

\subsubsection{Staphylococcus aureus}

S. aureus were enumerated using $3 \mathrm{M}$ Petrifilm ${ }^{\mathrm{TM}}$ Staph express count plate and disk (3M, USA). After incubation 
at $37^{\circ} \mathrm{C}$ for $1 \mathrm{~d}$, red-violet colonies on the plate were counted and presumed $S$. aureus colonies (having pink zones) were confirmed using the Staph express disk after incubation at $37^{\circ} \mathrm{C}$ for $3 \mathrm{~h}$.

\subsubsection{Listeria spp.}

Listeria spp. were enumerated using $3 \mathrm{M}$ Petrifilm ${ }^{\mathrm{TM}}$ environmental Listeria plate (3M, USA), after incubation at $37^{\circ} \mathrm{C}$ for $26-30 \mathrm{~h}$.

\subsection{Statistical analysis}

All microbial counts were converted to the base- 10 logarithm of the number of colony forming units per $\mathrm{ml}$ of buffalo milk samples $(\log \mathrm{cfu} / \mathrm{ml})$, and from these, means and their standard deviations were calculated. Data were analyzed using analysis of variance (ANOVA) through the general linear models (GLM) procedure of the statistical analysis system software (SAS version 9.00, SAS Institute, Inc., 2000). Least significant differences were used to separate means at $p<0.05$.

\section{Results and discussion}

\subsection{Chemical analysis}

Results obtained from the chemical analyses of buffalo milk are presented in Table 1. Buffalo milk had higher crude protein, fat, lactose and total solid contents than those reported for cow milk (Fundora et al., 2001; Lindmark-Månsson, Fondén, \& Pettersson, 2003), indicating higher nutrient density in buffalo milk. The average fat $(7.59 \pm 1.31 \% \mathrm{v} / \mathrm{v})$ and lactose $(4.74 \pm 0.20 \% \mathrm{w} / \mathrm{w})$ contents were slightly higher than those reported by Najdenova and Dimitrov (2003), but lower than found by Supino et al. (2004). The latter reported average fat and lactose contents of buffalo milk from 99 farms in Italy, of $8.27 \%$ and $4.81 \%$, respectively. The average crude protein $(4.86 \pm 0.44 \% \mathrm{w} / \mathrm{w})$, ash $(0.85 \pm 0.05 \% \mathrm{w} / \mathrm{w})$, and total solids $(18.44 \pm 1.56 \% \mathrm{w} / \mathrm{w})$ content and the average $\mathrm{pH}$ $(6.65 \pm 0.13)$ of Chinese buffalo milk were similar to values reported elsewhere (Fundora et al., 2001; Han \& Ding, 1994).
Chemical composition data were studied by analysis of variance. Total solids, fat, crude protein, and ash of crossbreeds $\mathrm{F}_{1}$ and $\mathrm{F}_{2}$ were significantly higher $(p<0.05)$ than those of the river buffalo Murrah and Nili-Ravi. The lactose content of Murrah was significantly higher $(p<0.05)$ than those of other breeds. It is not difficult to see that the total solid, fat, crude protein, and ash content of the multiple crossbreed were higher than the values of river buffalo but lower than those of $F_{1}$ and $F_{2}$. Our findings are in agreement with those of Zhang, Yang, Tan, and Zhuge (2004) who reported that total solids, protein, fat, lactose, ash and non-fat-solids content of crossbreeds were higher than those of pure river buffalo, but lower than the local swamp buffalo. This ranking was to be expected; considering that the swamp buffalo milk has higher nutrient levels than the river buffalo milk (Amarjit \& Toshihiko, 2003; Han \& Ding, 1994), the milk composition of the crossbreeds is expected in between that of milk from swamp and river buffalo. The inherited trait of milk composition, as crossbreeding continued, was stabilized during onward generations, apparently to ultimately reach a steady equilibrium in the multi-crossbreed. Since buffalo in China mainly consist of the crossbreed type, its physicochemical properties represent the current buffalo milk in China.

Similar as for cow milk (Lindmark-Månsson et al., 2003), in addition to the type of breeds, other factors such as forage, feeding systems, milking frequency, milking method, seasonal changes and lactation period, will exert an effect on the physicochemical parameters of buffalo milk (Suman et al., 1998).

\subsection{Microbiological analyses}

The microflora of buffalo milk is presented in Tables 2 and 3. Differences among milks from different buffalo breeds were studied by variance of analysis (Table 2). Of all breeds, the highest $(p<0.05)$ average loads of TC, LAB and coliforms were observed in Murrah. No significant differences were observed with respect to the average counts of fungi and E. coli.

Buffalo milk contained an average TC of $5.59 \pm 0.11 \mathrm{log}$ $\mathrm{cfu} / \mathrm{ml}$. This level marginally meets the Chinese national

Table 1

Chemical analyses of buffalo milk

\begin{tabular}{|c|c|c|c|c|c|c|}
\hline Breed & Fat $(\% \mathrm{v} / \mathrm{v})$ & Protein $(\% \mathrm{w} / \mathrm{w})$ & Lactose $(\% \mathrm{w} / \mathrm{w})$ & Total solids $(\% \mathrm{w} / \mathrm{w})$ & $\mathrm{pH}$ & $\operatorname{Ash}(\% \mathrm{w} / \mathrm{w})$ \\
\hline $\mathrm{M}(n=16)$ & $6.57 \pm 1.21^{*}, \mathrm{a}$ & $4.27 \pm 0.43^{\mathrm{a}}$ & $5.07 \pm 0.13^{\mathrm{a}}$ & $16.69 \pm 1.22^{\mathrm{a}}$ & $6.53 \pm 0.28^{\mathrm{ab}}$ & $0.79 \pm 0.05^{\mathrm{a}}$ \\
\hline $\mathrm{N}(n=16)$ & $6.53 \pm 1.28^{\mathrm{a}}$ & $4.16 \pm 0.20^{\mathrm{a}}$ & $4.56 \pm 0.10^{\mathrm{b}}$ & $17.14 \pm 1.34^{\mathrm{a}}$ & $6.39 \pm 0.06^{\mathrm{b}}$ & $0.81 \pm 0.03^{\mathrm{a}}$ \\
\hline $\mathrm{F}_{\mathrm{H}}(n=16)$ & $7.56 \pm 0.90^{\mathrm{a}}$ & $4.75 \pm 0.53^{\mathrm{b}}$ & $4.61 \pm 0.20^{\mathrm{b}}$ & $18.22 \pm 1.24^{\mathrm{ab}}$ & $6.39 \pm 0.11^{\mathrm{b}}$ & $0.84 \pm 0.06^{\mathrm{ab}}$ \\
\hline $\mathrm{F}_{1}(n=32)$ & $8.81 \pm 1.89^{\mathrm{b}}$ & $5.23 \pm 0.45^{\mathrm{c}}$ & $4.80 \pm 0.22^{\mathrm{b}}$ & $19.75 \pm 2.29^{\mathrm{b}}$ & $6.70 \pm 0.29^{\mathrm{a}}$ & $0.88 \pm 0.07^{\mathrm{b}}$ \\
\hline Average & $7.59 \pm 1.31$ & $4.86 \pm 0.44$ & $4.74 \pm 0.20$ & $18.44 \pm 1.56$ & $6.65 \pm 0.13$ & $0.85 \pm 0.05$ \\
\hline
\end{tabular}

$\mathrm{M}$ (Murrah), N (Nili-Ravi) - river buffalo; $\mathrm{F}_{1}, \mathrm{~F}_{2}$ - crossbreed buffalo (river buffalo $\hat{\jmath} \times$ swamp buffalo + ) 1st and 2nd generations; $\mathrm{F}_{\mathrm{H}}-$ crossbreed buffalo (multi-crossbreed); $n$ - number of samples.

${ }^{\text {abc }}$ Means bearing different superscripts in the same column differ significantly $(p<0.05)$.

${ }^{*}$ Means \pm SD. 
Table 2

Microbiological loads of buffalo milk ( $\log \mathrm{cfu} / \mathrm{ml})$

\begin{tabular}{|c|c|c|c|c|c|c|c|}
\hline Breed & $\mathrm{TC}$ & BS & LAB & Fungi & Coliforms & E. coli & S. aureus \\
\hline $\mathrm{M}(n=16)$ & $6.51 \pm 0.27^{*}, \mathrm{a}$ & $3.20 \pm 0.24^{\mathrm{a}}$ & $5.48 \pm 0.13^{\mathrm{a}}$ & $1.97 \pm 0.82^{\mathrm{a}}$ & $3.95 \pm 0.07^{\mathrm{a}}$ & $1.89 \pm 0.40^{\mathrm{a}}$ & $2.05 \pm 0.58^{a}$ \\
\hline $\mathrm{N}(n=16)$ & $5.09 \pm 0.53^{\mathrm{b}}$ & $1.36 \pm 0.52^{\mathrm{b}}$ & $4.02 \pm 0.59^{\mathrm{b}}$ & $1.33 \pm 0.46^{\mathrm{a}}$ & $2.16 \pm 0.30^{\mathrm{b}}$ & $1.80 \pm 0.23^{\mathrm{a}}$ & $1.95 \pm 0.36^{\mathrm{a}}$ \\
\hline $\mathrm{F}_{\mathrm{H}}(n=16)$ & $5.64 \pm 0.74^{\mathrm{b}}$ & $2.11 \pm 0.33^{\mathrm{b}}$ & $4.77 \pm 0.51^{\mathrm{ab}}$ & $1.29 \pm 0.48^{\mathrm{a}}$ & $1.80 \pm 0.10^{\mathrm{b}}$ & $1.15 \pm 0.36^{\mathrm{a}}$ & $2.82 \pm 0.13^{\mathrm{b}}$ \\
\hline $\mathrm{F}_{2}(n=32)$ & $5.56 \pm 0.39^{\mathrm{b}}$ & $3.63 \pm 0.10^{\mathrm{a}}$ & $4.33 \pm 1.16^{\mathrm{ab}}$ & $2.00 \pm 0.38^{\mathrm{a}}$ & $2.21 \pm 0.80^{\mathrm{b}}$ & $1.87 \pm 0.46^{\mathrm{a}}$ & $1.21 \pm 0.09^{\mathrm{c}}$ \\
\hline $\mathrm{F}_{1}(n=32)$ & $5.17 \pm 0.34^{\mathrm{b}}$ & $3.08 \pm 0.98^{\mathrm{a}}$ & $4.54 \pm 0.65^{\mathrm{ab}}$ & $2.01 \pm 0.33^{\mathrm{a}}$ & $2.41 \pm 0.33^{\mathrm{b}}$ & $1.65 \pm 0.72^{\mathrm{a}}$ & $2.15 \pm 0.65^{\mathrm{a}}$ \\
\hline Average & $5.59 \pm 0.11$ & $2.31 \pm 0.09$ & $4.62 \pm 0.12$ & $1.79 \pm 0.23$ & $2.42 \pm 0.12$ & $1.53 \pm 0.17$ & $1.68 \pm 0.19$ \\
\hline
\end{tabular}

M (Murrah), N (Nili-Ravi) - river buffalo; $F_{1}, F_{2}$ - crossbreed buffalo (river buffalo $\widehat{x} \times$ swamp buffaloo) 1st and 2nd generations; $F_{H}-$ crossbreed buffalo (multi-crossbreed); $n$ - number of samples.

${ }^{a b c}$ Means bearing different superscripts in the same column differ significantly $(p<0.05)$; TC - total count of mesophilic aerobic bacteria; LAB - lactic acid bacteria; BS - bacterial endospores.

${ }^{*}$ Means $\pm \mathrm{SD}$.

Table 3

Microflora of 112 samples of buffalo milk (all breeds)

\begin{tabular}{lrrrrrrl}
\hline Type of microorganism & \multicolumn{6}{c}{ Percentage of samples with $\log \mathrm{N} \mathrm{cfu} / \mathrm{ml}$} \\
\cline { 2 - 8 } & $<1$ & $1-2$ & $2-3$ & $3-4$ & $4-5$ & $5-6$ & $6-7$ \\
\hline TC & & & & & 34 & 52 & 14 \\
LAB & 25 & 19 & 35 & 12 & 9 & & \\
BS & 9 & 67 & 24 & & & & \\
Fungi & 5 & 21 & 64 & 7 & 3 & & \\
Coliforms & 21 & 53 & 26 & & & & \\
E. coli & 24 & 43 & 22 & 11 & & & \\
S. aureus & 100 & & & & & & \\
Listeria spp. &
\end{tabular}

TC - total count of aerobic bacteria; LAB - lactic acid bacteria; BS bacterial endospores.

standard (GB 19301-2003) for raw milk, as well as the EU specification (EU Directive 92/46/EEC) for raw buffalo milk, both being $5 \times 10^{5} \mathrm{cfu} / \mathrm{ml}$. The main reason for these relatively high counts of TC should be ascribed to inadequate sanitary conditions during milking, collection and transport. Buffalo milk in Italy (Supino et al., 2004) had total bacterial counts of $5.23 \log \mathrm{cfu} / \mathrm{ml}$, which is of the same order as our data.

LAB constituted a major part of the microflora with an average of $4.62 \pm 0.12 \mathrm{log} \mathrm{cfu} / \mathrm{ml}$. Boycheva et al. (2002) observed that LAB and psychrotrophs predominated in Bulgarian buffalo milk. As the relatively high numbers of LAB will cause undesirable fermentative acidification of raw milk, effective measures should be taken to avoid this kind of spoilage.

The average count of bacterial endospores was $2.31 \pm$ $0.09 \log \mathrm{cfu} / \mathrm{ml}$, these usually originate from the soil, manure, and forages (Zhou, 1998). Although only $9 \%$ of the samples exceeded the tolerated level of $10^{4} \mathrm{cfu} / \mathrm{ml}$ (Table 3 ), spores nevertheless pose a potential threat for the quality of buffalo milk products, since they might survive pasteurization and other heat treatments (Te Giffel, 2003).

The average load of $S$. aureus was $1.68 \pm 0.19 \log \mathrm{cfu} /$ ml. Fook, Aminah, and Mohd (2004) reported considerably higher levels of $S$. aureus in raw cow milk, with $35 \%$ of the samples having $4.2 \log \mathrm{cfu} / \mathrm{ml}$. Since $S$. aureus is potentially hazardous at $>10^{4} \mathrm{cfu} / \mathrm{ml}$ (Han, Sesenna,
Beumer, \& Nout, 2005), all buffalo milk samples were within an acceptable level. However, since $76 \%$ samples contained $S$. aureus, growth of $S$. aureus must be prevented to avoid potential risk. The presence of Listeria spp. was not detected in any of the samples.

The average levels of coliform bacteria and E. coli were $2.42 \pm 0.12$ and $1.53 \pm 0.17 \log \mathrm{cfu} / \mathrm{ml}$, respectively. These counts were higher than those reported by Desmasures, Bazin, and Gueguen (1997), who reported that $84 \%$ of samples of French cow milk had coliform counts $<100 \mathrm{cfu} / \mathrm{ml}$ and $80 \%$ had E. coli counts $\leqslant 10 \mathrm{cfu} / \mathrm{ml}$. E. coli may be considered an indicator microorganism of faecal contamination and other enteric pathogens. Its occurrence in milk may originate from the external surface of the udder, milking machines, manual milking, handling, and inferior quality of water (Fook et al., 2004).

\section{Conclusion}

The chemical composition of buffalo milk indicates that it is a rich source of nutrients and thus offers excellent opportunities for the development of local dairy industry and to meet the public need for nutrition. The microbiological quality was only marginally acceptable with respect to the total bacteria count. Nevertheless, the presence of pathogenic and indicator bacteria, such as E. coli, coliforms, and $S$. aureus, indicate that to the growth of these organisms may lead to a hazard against public health. Therefore, it is highly recommended that hygienic practices and regulations, such as on-site pasteurisation and implementation of HACCP following established standards, should be introduced to facilitate the production of buffalo milk of high quality and safety.

\section{Acknowledgements}

This work was supported by the Project JD100190533 of the Education Bureau of Beijing, China. The authors thank $\mathrm{Li}-\mathrm{Li} \mathrm{Li}$ and Wei Si of China Agricultural University and staff of Yunnan Dali Laisr Dairy Co. Ltd. for their valuable assistance. 


\section{References}

Amarjit, S. N., \& Toshihiko, N. (2003). Role of buffalo in the socioeconomic development of rural Asia: Current status and future prospectus. Animal Science Journal, 74, 443-445.

Boycheva, S., Dimitrov, T., Tsankova, M., \& Iliev, T. (2002). Investigation on microflora of buffalo milk. Bulgarian Journal of Agricultural Science, 8, 279-282.

Desmasures, N., Bazin, F., \& Gueguen, M. (1997). Microbiological composition of raw milk from selected farms in the Camembert region of Normandy. Journal of Applied Microbiology, 83, 53-58.

EU Directive 92/46/EEC (2004). Health rules for the production and placing on the market of raw milk, heat-treated milk and milk-based products. EU: EU Directive.

FAO (2004). Available from http://faostat.fao.org/faostat/collections? subset $=$ agriculture.

Fook, Y. C., Aminah, A., \& Mohd, K. A. (2004). Bacteriological quality and safety of raw milk in Malaysia. Food Microbiology, 21, 535-541.

Fundora, O., Gonzalez, M. E., Lezcano, O., Montejo, A., Pompa, N., \& Enriquez, A. V. (2001). A comparative study of milk composition and stability of Murrah river buffaloes and Holstein cows grazing star grass. Cuban Journal of Agricultural Science, 35, 219-222.

GB/T 16285-1996 (1996). Method for determination of glucose in food: enzyme-colorimetric method and enzyme-electrode method. Beijing, China: China National Standard (in Chinese).

GB 19301-2003 (2003). Hygenic Standard for Raw Milk. Beijing, China: China National Standard.
Han, G., \& Ding, Q. B. (1994). A physiochemical study on buffalo milk in China. Journal of South China Agricultural University, 15(4), 92-97 (in Chinese).

Han, B.-Z., Sesenna, B., Beumer, R. R., \& Nout, M. J. R. (2005) Behaviour of Staphylococcus aureus during sufu production at laboratory scale. Food Control, 16, 243-247.

Lindmark-Månsson, H., Fondén, R., \& Pettersson, H. E. (2003). Composition of Swedish dairy milk. International Dairy Journal, 13 , 409-425.

Najdenova, N., \& Dimitrov, T. (2003). Technological qualities of buffalo milk from the Bulgarian Murrah breed for production of Bulgarian yoghurt. Journal of Animal Science, 40(5), 33-35.

Suman, C. L., Saxena, M. M., Pandey, H. S., Dubey, P. C., Rajendra, S., Sanyal, M. K., et al. (1998). Some factors affecting milk constituents yield of Murrah buffalo. Indian Veterinary Journal, 75(2), 176-177.

Supino, M. T., Gallo, M., Capo, G., Morena, C., Durante, G., \& Galiero, G. (2004). Buffalo milk produced in the province of Salerno: Evaluation of sanitary and product parameters. Bubalus Bubalis, 10, 22-26.

Te Giffel, M. C. (2003). Good hygienic practice in milk processing. In G. Smit (Ed.), Dairy processing, Improving quality (pp. 68-80). Boca Raton: CRC Press.

Zhang, C. X., Yang, B. X., Tan, J., \& Zhuge, Y. (2004). Sustainable development of Chinese buffalo milk industry. China Dairy Industry, $11,11-15$ (in Chinese).

Zhou, W. (1998). High quality raw milk production. China Dairy Industry, 26(1), 31-33 (in Chinese). 